\title{
Correction to: Are personnel with a past history of mental disorders disproportionately vulnerable to the effects of deployment-related trauma? A cross- sectional study of Canadian military personnel
}

Peter J. H. Beliveau ${ }^{1 *}$, Hugues Sampasa-Kanyinga ${ }^{1,2}$, lan Colman ${ }^{2}$ and Mark A. Zamorski ${ }^{1,3^{\wedge}}$

Correction to: BMC Psychiatry (2019) 19:156

https://doi.org/10.1186/s12888-019-2146-z

Following publication of the original article [1], we have been notified that the copyright holder needs to be changed from $\odot$ The Author(s) to @Crown.

The original article has been corrected.

\section{Author details}

${ }^{1}$ Directorate of Mental Health, Canadian Forces Health Services Group, 101 Colonel By Drive Carling Campus, Building 9, Ottawa, ON K1A OK2, Canada. ${ }^{2}$ School of Epidemiology, Public Health and Preventive Medicine, University of Ottawa, Ottawa, ON, Canada. ${ }^{3}$ Department of Family Medicine, University of Ottawa, Ottawa, ON, Canada.

Received: 19 June 2019 Accepted: 19 June 2019

Published online: 01 July 2019

\section{Reference}

1. Beliveau PJH, et al. Are personnel with a past history of mental disorders disproportionately vulnerable to the effects of deployment-related trauma? A cross-sectional study of Canadian military personnel. BMC Psychiatry. 2019;19:156. https://doi.org/10.1186/s12888-019-2146-z.

\footnotetext{
* Correspondence: Peter.Beliveau@forces.gc.ca

Deceased

'Directorate of Mental Health, Canadian Forces Health Services Group, 101

Colonel By Drive Carling Campus, Building 9, Ottawa, ON K1A OK2, Canada

Full list of author information is available at the end of the article
}

(c) The Author(s). 2019 Open Access This article is distributed under the terms of the Creative Commons Attribution 4.0 International License (http://creativecommons.org/licenses/by/4.0/), which permits unrestricted use, distribution, and reproduction in any medium, provided you give appropriate credit to the original author(s) and the source, provide a link to the Creative Commons license, and indicate if changes were made. The Creative Commons Public Domain Dedication waiver (http://creativecommons.org/publicdomain/zero/1.0/) applies to the data made available in this article, unless otherwise stated. 